Li Yinan

Katedra Języka Polskiego, Pekiński Uniwersytet Języków Obcych

\title{
Czuła narracja: nowe oblicze literatury polskiej w oczach Chińczyków
}

\section{Wstęp}

Recepcja literatury polskiej w Chinach jest w ostatnich dekadach popularnym zagadnieniem badawczym zarówno w Polsce, jak i w Państwie Środka. Na początku xxi wieku chińscy badacze zaczęli pisać rozprawy naukowe poświęcone tłumaczeniu dzieł polskich autorów. Warto tutaj wymienić przede wszystkim dorobek Wang Youguia, któremu zawdzięczamy pierwsze studia o tej tematyce: Literaturę polska w Chinach i Przekłady literatury polskiej na język chiński. Zagadnienie to zostało pogłębione w kolejnych opracowaniach naukowych, począwszy od 2010 roku pojawiały się artykuły chińskich polonistów, takich jak Yi Lijun, Wu Lan i Li Yinan, opublikowane m.in. w pismach „Azja i Pacyfik” oraz „Postscriptum Polonistyczne”. Li Yinan w jednym ze swoich artykułów podkreśliła różnice międzykulturowe w odbiorze współczesnej literatury kobiecej, zaś Wu Lan [2019] w opracowaniu Z notatnika tłumacza literatury polskiej i chińskiej opisała swoje doświadczenia związane z tłumaczeniem tekstów Ryszarda Kapuścińskiego i Adama Zagajewskiego oraz podsumowała chińskie studium badań nad Stefanem Żeromskim, Czesławem Miłoszem, Brunonem Schulzem czy Adamem Mickiewiczem. Panoramiczny przegląd recepcji literatury polskiej w Chinach pod względem translatorskim, krytycznolite- 
rackim i promocyjnym zaprezentowała Li Yinan [2017] w książce Literatura polska $w$ Chinach, nominowanej do Nagrody im. Jana Kochanowskiego. W tym obszernym opracowaniu zaproponowano ogólną ocenę sposobu przyjęcia literatury polskiej przez Chińczyków, oszacowano też rozmiary tego zjawiska i odwzorowano wizerunek Polski i Polaków powstający w świadomości obywateli Państwa Środka. Było to możliwe dzięki opisom i mapowaniu przekładów oraz ukazaniu krytycznoliterackiego przyjęcia literatury polskiej przez chińskich czytelników w układzie historycznym, pod kątem tłumaczonych pisarzy, tłumaczy oraz strategii wydawnictw i czasopism. W swojej recenzji Literatury polskiej w Chinach Choi Sungeun (Estera Czoj) z Uniwersytetu Stosunków Zagranicznych Hankuk podkreśliła, że „dzięki zawartym w niej myślom i tezom oraz dokładnym eksperckim badaniom [publikacja - L.Y.] doskonale spełnia funkcję przewodnika po literaturze polskiej w Chinach” [Li 2017: okładka].

Po publikacji tej książki literatura polska znalazła się w orbicie rosnącej popularności i zyskała szerszy zasięg i zainteresowanie wśród Chińczyków. Są dwie główne przyczyny tego zjawiska. Pierwsza jest związana z rozwojem współpracy chińsko-polskiej w ramach mechanizmu „17 + 1" (do 2019 roku „16 + 1”) i inicjatywy „Pasa i Szlaku”. Na tej podstawie instytucje kulturalne obu państw starają się promować kulturę polską, przede wszystkim literaturę, w celu lepszego wzajemnego poznania i zacieśnienia kontaktów międzyludzkich. Zgodnie z teorią André Lefevere'a [1992], belgijskiego teoretyka przekładu, patronat odgrywa tutaj istotną rolę, gdyż posiada mandat do tego, aby publikować pozycje, które uważa za akceptowalne, oraz blokować wydawanie pozostałych. W ten sposób sprzyja rozwojowi literatury lub go hamuje. Drugą przyczyną są nagrody: Bookera i Nobla w dziedzinie literatury przyznane Oldze Tokarczuk. Spotęgowały one rezonans krytyczno-czytelniczy wśród miłośników literatury zagranicznej, a zwłaszcza polskiej. Nagroda Nobla, uznawana za najbardziej prestiżową międzynarodową nagrodę literacką na świecie, jest bardzo ceniona przez Chińczyków. Jej przyznanie jest nie tylko powodem do dumy, ale przede wszystkim potwierdzeniem indywidualnego rozwoju literackiego. Nobliści i ich dzieła literackie przyciągają coraz 
większą uwagę czytelników, tłumaczy i wydawnictw. Wyliczenie przekładów opublikowanych w ostatnich sześciu latach ${ }^{1}$ pokazuje, że Olga Tokarczuk, Czesław Miłosz i Wisława Szymborska zajmują uprzywilejowaną pozycję w całym dorobku chińskich tłumaczy.

Li Yinan [2017: 9] w Literaturze polskiej w Chinach stwierdziła, że

dzisiaj, w dobie globalizacji, unikalny charakter literatury polskiej ma specjalne znaczenie dla ochrony różnorodności kulturowej, gdyż jej twórcy przywiązują wielką wagę do dziedzictwa i propagowania tradycji narodowej, podkreślania własnej tożsamości, rozważań dotyczących rozwoju i perspektyw narodowych. Kiedy w Chinach mówi się o Polsce, przywołuje się ją jako ojczyznę Fryderyka Chopina, jako kraj, w którym rodacy Adama Mickiewicza przeżywali tragedie historyczne i udowadniali swój patriotyzm, odwagę i silną wolę w dążeniu do wolności i niepodległości. Literatura polska jest dla Chińczyków swoistym synonimem pamięci o własnej - nieraz bardzo skomplikowanej - historii i kulturze.

Autorka, obserwując najświeższe zjawisko z tej dziedziny, zauważyła, że powyższe stwierdzenie w pewnym stopniu zgadza się z cechą charakteru wachlarza przekładów polskich utworów literackich i osiągnięć w badaniu literatury polskiej w latach 2015-2020. Nie należy natomiast ignorować faktu, że wybór tłumaczy i wydawnictw oraz sposób odbioru chińskich czytelników bardzo się zmienily.

\section{Najnowsze przekłady opublikowane na rynku chińskim}

W ostatnich kilku latach zainteresowanie literaturą polską w Chinach rośnie nieustannie. Według statystyki zamieszczonej w książce Literatura polska $w$ Chinach w latach 2000-2014 powstało 136 prze-

1 Ta praca bazuje na danych statystycznych zbieranych przez autorkę w latach 2015-2020, gdyż przekłady powstałe do 2014 roku zostały już uwzględnione w książce Literatura polska w Chinach. 
kładów. W kolejnym okresie, w latach 2015-2020, liczba ta wyniosła 99, a tylko w styczniu 2021 roku ukazało się na chińskim rynku wydawniczym aż 8 pozycji. Wszystkie dane wykazują, jak z jednej strony starania promocyjne patronatu znacząco wpływały na rynek wydawniczy, a z drugiej strony, jak on sam przyciąga chińskich czytelników.

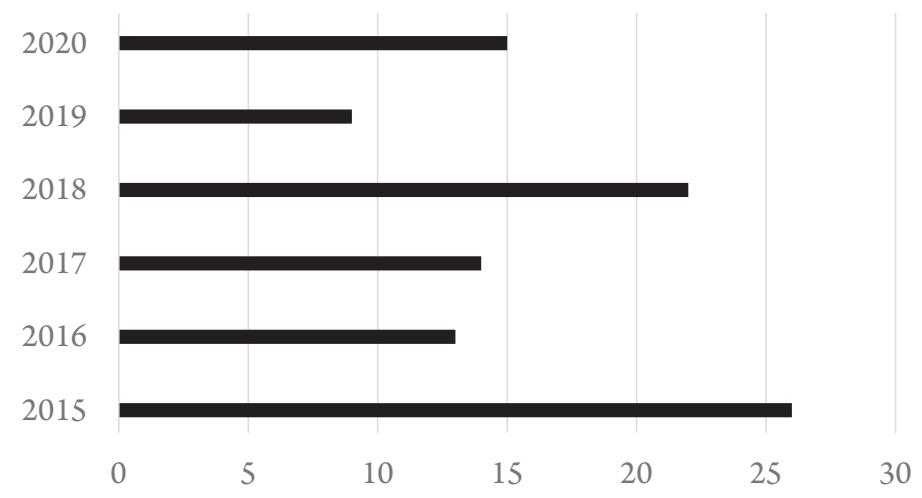

Wyk. 1. Liczba przekładów dzieł literatury polskiej w Chinach w poszczególnych latach

W szczegółowych zestawieniach z okresu 2015-2020 (wyk. 1 i 2) można dostrzec dwie prawidłowości. Po pierwsze, dzieła polskich noblistów zajmują ważne miejsce w tłumaczeniu literatury polskiej w Chinach. Wisława Szymborska, Czesław Miłosz, Henryk Sienkiewicz, Olga Tokarczuk i Władysław Reymont (w tej kolejności) znajdują się w pierwszej dziesiątce najchętniej tłumaczonych pisarzy. Po drugie, twórczość Andrzeja Sapkowskiego, a szczególnie jego Wiedźmin, wzbudziła ogromne zainteresowanie wśród Chińczyków za sprawą adaptacji gry komputerowej. Był to fenomen w środowisku literackim i artystycznym. Alternatywna rzeczywistość wykreowana w tym cyklu zachęcała Chińczyków do poznania polskiej fantastyki i literatury nurtu fantasy.

W analizowanym okresie ukazało się 14 przekładów Szymborskiej, m.in. Czarna piosenka (2016, 2019 ponowne wydanie), Tutaj (2018), Ludzie na moście (2019). Szczególną uwagę należy zwrócić 


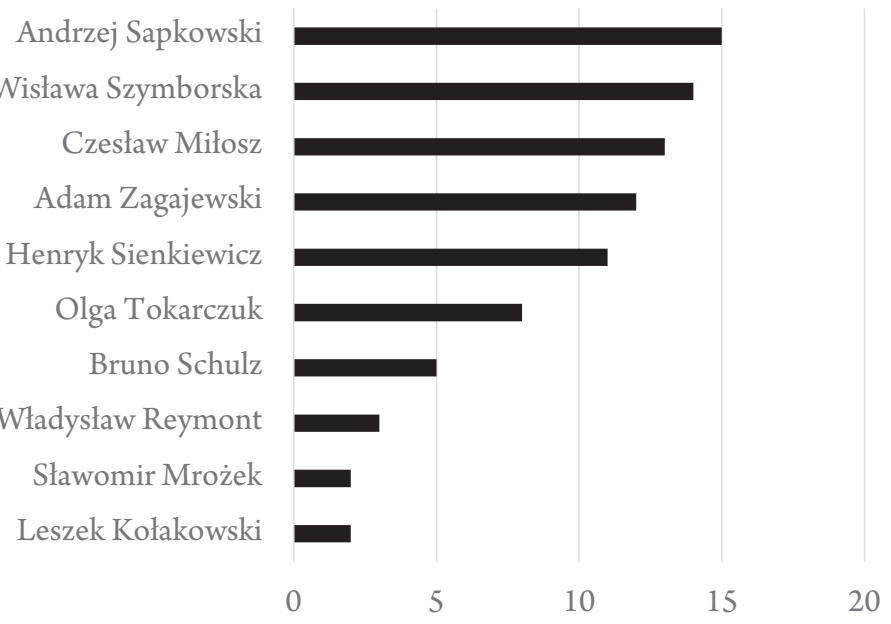

Wyk. 2. Liczba przekładów dzieł poszczególnych pisarzy polskich w Chinach

na monumentalną serię Dzieła Wszystkie Wisławy Szymborskiej, wydaną przez Instytut Wydawniczy Wschodu (Dongfang Chuban Zhongxin) w Szanghaju w 2019 roku. W tej serii opublikowano dwutomowy Wybór wierszy Wistawy Szymborskiej, dwutomowe Lektury nadobowiazkowe i Pocztę literacka, czyli jak zostać (lub nie zostać) pisarzem. Cała seria stała się hitem tegorocznego rynku wydawniczego. Najpopularniejsze dzienniki i periodyki z dziedziny literatury i sztuki w Chinach, takie jak: portal Dziennik Ludowy (Renminwang), „Chińska Gazeta Dziennikarska, Radia i Telewizji” („Zhongguo Xinwen Guangdian Chubanbao”), „Gazeta Literatury” („Wenxuebao”), „Wiadomości Wieczorne Jangcy” („Yangzi Wanbao"), promowały to wydanie, oceniając, że stanowi ono

kompletny zbiór będący pierwszym obszernym i panoramicznym pokazem dorobku literackiego polskiej noblistki, obejmującym poezję, prozę, komentarze i inne formy literackie. Wydanie chińskiej wersji wszystkich dzieł Szymborskiej umożliwia chińskim czytelnikom pełniejsze odczytanie, zrozumienie poetki, poznawanie istoty jej światopoglądu i osobowości, a także zbliżenie się do piękna literatury polskiej i tempera- 
mentu Polaków. Tłumaczenie wszystkich prac jest dokładne i eleganckie, z powodzeniem oddało piękno i porywającą narrację oryginalnego dzieła w języku chińskim². [Xuan 2020]

Warto zaznaczyć, że zespół tłumaczy składał się z przedstawicieli trzech pokoleń polonistów, na których czele stał zasłużony tłumacz literatury polskiej, laureat nagrody za całokształt Związku Chińskich Tłumaczy. To najwyższego szczebla chińska nagroda dla thumaczy. Powodzenie tego wydania zachęciło Instytut Wydawniczy Wschodu do dalszej promocji. Na początku 2021 roku opublikowano cztery zbiory Szymborskiej: Między toskotem a cisza, Jak ktoś, kto wie, że nikt go tu nie czeka, Mam oczywistą duszę jak śliwka ma pestkę, Dlatego żyjemy, przetłumaczone przez Lin Honglianga.

Miłosz, jako noblista i jeden z najwybitniejszych przedstawicieli poezji polskiej, niezmiennie od lat znajduje się w centrum zainteresowania chińskich czytelników. W kilku czasopismach chińskich, m.in. w „Miesięczniku Poezji” („Shige Yuekan”) i „Kulturze Szanghajskiej” („Shanghai Wenhua”), ukazały się wybrane wiersze Miłosza, np. Młody człowiek i sekrety, Dumny z bycia ssakiem. Z esejów warto wymienić Pieska przydrożnego (2016) i Ziemię Urlo (2018) - oba opublikowane przez Wydawnictwo Huacheng (Huacheng Chubanshe). Przekład Pieska przydrożnego był udaną próbą młodej tłumaczki Zhao Weiting, której kunsztowny język chiński i znakomita umiejętność translatorska zyskały uznanie krytyków. Niektórym czytelnikom wydawało się, że eseje Miłosza są przystępniejsze niż jego intelektualno-moralizatorska poezja, ale było to tylko złudzenie. Sama tłumaczka napisała w przedmowie, że utwory Miłosza charakteryzują się powracaniem do minionych chwil, spojrzeniem na problem od wewnątrz, alegorią i kontemplacyjnym charakterem. Są przez to czasami dość nużące, a ich zrozumienie wymaga wysiłku. Twórczość Miłosza jest nierozerwalnie związana z pamięcią historyczną $\mathrm{xx}$ wieku, tematyką Wilna, polskości i katolicyzmu. Dodatkowo nagromadzenie aluzji, nazw miejsc i osób również sprawia, że utwory noblisty są trudne

2 Wszystkie tłumaczenia w tekście zostały wykonane przez autorkę bezpośrednio z języka chińskiego - L.Y. 
w odbiorze. Czytelnicy mogą się poczuć zdezorientowani także dlatego, że autor jednocześnie pragnie współczucia i zachowuje dystans. Wewnętrznie skonfliktowany miota się pomiędzy potrzebą pisania a niewiarą w jego ocalającą czy choćby terapeutyczną moc.

Niezależnie od powyższych cech Miłoszowego pisarstwa Piesek przydrożny cieszył się popularnością. Na największym portalu czytelniczym w Chinach, Douban (platforma podobna do polskiej witryny Lubimyczytać.pl), książka ta zdobyła 8,2 punktu w skali 10-punktowej. Tłumaczka Zhao Weiting, jako czytelniczka mająca „bezpośredni kontakt duchowy” z poetą, stwierdziła:

Gdy po raz pierwszy przeczytałam tę książkę, to naprawdę trudno było mi ją zrozumieć. Po pierwsze, nie dorównywałam autorowi zarówno pod względem wiedzy, jak i doświadczenia historycznego. Po drugie, teksty obecne w pierwszej części książki były podobne do esejów, tj. krótkie w formie, ich język był „pełen rezerwy”, a niektóre z rozdziałów miały wyraźnie prywatny charakter, przypominały wewnętrzny monolog, zapiski ze snów, dawne wspomnienia, fragmenty lub kilka zakurzonych szkiców. Gdybyśmy porównali proces czytania do alpinizmu, to powyższe dwa punkty zwiększają trudność wspinaczki. Jednak po wejściu na szczyt można obejrzeć ten labirynt z lotu ptaka i przekonać się, że to, co najcenniejsze w czytaniu, to konieczność wysilenia swojego umysłu i zrozumienia niektórych fragmentów. [Miłosz 2016: 2]

Kolejnym istotnym wydarzeniem w dziejach tłumaczenia poezji Miłosza jest wydanie czterotomowego zbioru wierszy poety w roku 2018. Zebrano w nim 336 wierszy pisanych od 1931 do 2001 roku. Serię tę można więc uznać za pierwsze i najpełniejsze w świecie chińskojęzycznym tłumaczenie wierszy Miłosza, które wypełniło luki w recepcji jego poezji. Poza tym wydanie to skupiło uwagę trzech wybitnych tłumaczy i polonistów chińskich: Yang Deyou, Lin Honglianga i Zhao Weiting, co podniosło walory językowe całego tłumaczenia, wysoko ocenionego przez krytykę chińską.

Podczas wydarzenia poświęconego promocji tego obszernego przekładu znany chiński poeta Ouyang Jianghe podzielił się 
swoimi refleksjami o poezji Miłosza. Jego zdaniem noblista był pod wplywem starej europejskiej edukacji oraz edukacji klasycznej. W porównaniu z innymi poetami był bardzo skomplikowaną osobą i wszechstronnie utalentowanym artystą, poetą, myślicielem, filozofem, przyrodnikiem i profesorem. Niejasność polszczyzny, którą posługuje się stosunkowo mała grupa ludzi, daje poezji pewną przestrzeń i możliwość zachowania oryginalności językowej. Z tych komentarzy można wyciągnąć wniosek, że twórczość Miłosza w oczach chińskich literatów ma charakter oryginalnej literatury o wyjątkowej genezie, co w pewnym sensie przemawia do poetów.

W dziedzinie poezji nie sposób pominąć dorobku Zbigniewa Herberta, który cieszy się popularnością w Polsce i na świecie, w tym także w Chinach. Wszyscy wiedzą, że wiele razy przyznawano mu nagrody literackie. Choć - mimo wielu nominacji - nigdy nie otrzymał Nagrody Nobla, jego pozycja w gronie polskich poetów wciąż jest wysoka. Chiński poeta i tłumacz Li Yiliang już w 2011 roku opublikował wiersze Herberta w „Poezji Jiangnan” („Jiangnan Shi”). W tym samym roku wybór wierszy poety w przekładzie Zhao Ganga, wyznaczonego do roli tłumacza przez właściciela praw autorskich do twórczości Herberta, został umieszczony we Wspótczesnej poezji świata [Zhao 2009]. Dwutomowy zbiór wierszy Herberta z 2019 roku stał się zwieńczeniem tłumaczenia jego twórczości w Chinach. To wyjątkowe, bo po raz pierwszy Herbert został przetłumaczony bezpośrednio z polskiego na chiński. Przekład obejmuje ponad 400 wierszy z dziewięciu tomów poety i ukazuje panoramicznie jego twórczość. Według tłumacza szczególną cechą twórczości Herberta jest niewątpliwie jego nieustanna eksploracja starożytnej cywilizacji europejskiej. W swoich utworach poeta z latwością i perfekcją nawiązuje do mitów, legend, bohaterów oraz ważnych wydarzeń z czasów starożytnych Grecji oraz Rzymu. Stara się poddać dekonstrukcji stare mity i postacie historyczne, zdjąć historyczną mgłę oraz celowo zastosowany kamuflaż, a także przywrócić istotę pierwotnych postaci i wydarzeń. Wskrzeszone za pomocą jego pióra obrazy i wydarzenia pozwalają nam ponownie zbadać historię oraz lepiej zrozumieć rzeczywistość [Zhao 2019: 10] We wstępie do tego tomu ambasador RP w Pekinie Wojciech Zającz- 
kowski podkreślił, że tłumacz nie tylko musi znaleźć odpowiedni balans pomiędzy systemami dwóch różnych od siebie języków, lecz także osiągnąć równowagę pomiędzy dwiema różnymi cywilizacjami, jakimi są Europa i Chiny. Twórczość Herberta jest mocno zakorzeniona w kulturze starożytnej Europy oraz biblijnych tradycjach, co bez wątpienia jest ogromnym wyzwaniem dla thumacza. W tej sytuacji musi on prawidłowo oddać znaczenie danego słowa oraz dogłębnie przeanalizować treść pełną różnorakich metafor, które zazwyczaj są niewyraźne, a nawet niezrozumiałe dla czytelnika spoza Europy. Ambasador wyraził też przekonanie, że chińscy czytelnicy wkrótce zauważą uniwersalne wartości w poezji Herberta [Zajączkowski 2019: 2].

Do grona polskich poetów cenionych przez Chińczyków należy jeszcze zaliczyć Zagajewskiego, który zajmuje w Chinach podobną pozycję do Herberta. Obaj nazywani są przez Chińczyków „laureatami bez lauru Nobla”. Ciekawe jest to, że Zagajewskim od 2015 roku zajmuje się właściwie tylko Li Yiliang, który w tym okresie wydał dziewięć tomów, m.in. Obrona żarliwości, Bez końca, $W$ cudzym pięknie, Pisać po polsku, Lekka przesada, Wybór wierszy Adama Zagajewskiego I i II, Niewidzialna ręka, Odwieczni wrogowie. Przekłady te nie wywołały jednak zbyt dużego zainteresowania wśród przeciętnych czytelników. O Zagajewskim na nowo zaczęto mówić, gdy porównywano go z Tokarczuk po przyznaniu jej Nagrody Nobla w dziedzinie literatury. Wielu chińskich literaturoznawców sądzi, że Zagajewski zajmuje w literaturze polskiej analogiczną pozycję do noblistki Tokarczuk, a różnice sprowadzają się do tworzywa: Zagajewski para się poezją, a Tokarczuk obcuje z prozą.

Tokarczuk weszła w horyzont chińskich czytelników już na początku XXI wieku. Odpowiednio w latach 2003 i 2007 zostały przetłumaczone przez Yi Lijun i Yuan Hanronga powieści Prawiek i inne czasy oraz Dom dzienny, dom nocny, opublikowane na Tajwanie. W późniejszych latach miały one kolejne wydania w Chinach kontynentalnych. O motywacji tłumaczenia twórczości Tokarczuk Yi Lijun wspomniała w wywiadzie:

[... ] rozmowa z Olgą Tokarczuk w roku 2005, kiedy uczestniczyła w pierwszym Światowym Kongresie Tłumaczy Litera- 
tury Polskiej w Krakowie, zachęciła mnie do kontynuowania promocji tej pisarki w Chinach.

Tokarczuk wyraziła wówczas radość i wdzięczność za znakomite tłumaczenie Yi Lijun które umożliwiło ogromnej liczbie chińskich czytelników poznanie jej twórczości. Tłumaczka z kolei stwierdziła, że po rozmowie z Tokarczuk zaczęła postrzegać jej dzieła jako swego rodzaju „literaturę poszukującą korzeni” [Zhao 2019]. Pisarka ciągle szuka korzeni narodu polskiego. Wiele elementów z polskiej historii zmityzowała, ale choć posługuje się narracją utkaną ze snów i powoli zacierających się archetypów, to zawsze pisze o konkretnej rzeczywistości. Wydane w pierwszej dekadzie Xxi wieku przekłady jej prozy umożliwiły Chińczykom spotkanie z oryginalną twórczością pisarki.

Wyjątkowy był oczywiście rok 2018, kiedy Tokarczuk otrzymała Nagrodę Bookera za powieść Bieguni. Powstało wówczas wiele opracowań krytyczno-naukowych i popularnonaukowych jej twórczości. Li Yinan napisała artykuł Olga Tokarczuk - mityczna i głęboka podróż literatury, opublikowany w „Gazecie Literatury i Sztuki” („Wenyibao”), w którym szkicowo przedstawiła sylwetkę pisarki i jej twórczość literacką. Zhao Gang w artykule Sens życia to podróż, zamieszczonym w „Gazecie Jasności” („Guangming Ribao”), skupił się na nagrodzonej powieści Bieguni. Wydawnictwo Houlang, które w roku 2017 opublikowało dwa przekłady autorstwa Yi Lijun, od razu zaczęło szukać tłumacza do Biegunów. W końcu anglistka Yu Shi podjęła wyzwanie i wydała ten przekład na początku 2020 roku, tuż po przyznaniu Tokarczuk Nagrody Nobla. W odróżnieniu od wersji anglojęzycznej, w której tytuł Bieguni został przetłumaczony jako Flights, chińska wersja zachowała oryginalne znaczenie „biegunów”, czyli nazwy odłamu rosyjskich staroobrzędowców, bieżeńców, wierzących, iż świat jest przesiąknięty złem, które ma do człowieka trudniejszy dostęp, gdy pozostaje on w ciągłym ruchu. Aby więc złu nie ulec, konieczne jest nieustanne przemieszczanie się. Pomimo faktu, że tłumaczka korzystała $z$ wersji angielskiej powieści, jej przekład na chiński spotkał się z ogromną popularnością wśród czytelników. Na portalu internetowym Douban pozycja ta otrzymała dziewięć punk- 
tów, a więc bardzo wysoką ocenę. Świadczy to o umiejętnościach translatorskich, dzięki którym książkę czyta się z wielką uwagą i dużą dozą refleksji.

10 października 2019 roku Akademia Szwedzka przyznała Tokarczuk Nagrodę Nobla (za rok 2018) w dziedzinie literatury. Fakt ten wzbudził wiele emocji na świecie, także w Chinach. Chińskie media niemalże natychmiast po werdykcie transmitowały wywiady ze znawcami literatury polskiej i wybitnymi tłumaczami. Nocą, tuż po ogłoszeniu decyzji jury, Centrum Studiów Polskich Pekińskiego Uniwersytetu Języków Obcych (PUJo) opublikowało artykuł o Tokarczuk, omawiający recepcję jej twórczości w Chinach. Z inicjatywy Redaktora Naczelnego Gao Xinga ukazał się specjalny numer czasopisma „Literatura w Świecie” poświęcony Tokarczuk i Peterowi Handkemu. Zamieszczono w nim przekłady opowiadań noblistki: Szafa, Deus ex, Numery, Życzenie Sabiny, Podmiot, Wieczór autorski, Skoczek. Pracy translatorskiej podjęli się głównie najmłodsi tłumacze-poloniści. Ponadto we wspominanym numerze opublikowano przemowę noblowską w tłumaczeniu Li Yinan i interpretację wystąpienia Czuly i zagorzały głos dla cichego świata - odczytanie przemówienia Olgi Tokarczuk podczas ceremonii wręczenia Nagrody Nobla. W tym tekście Zhao Gang dzieli się swoimi refleksjami na temat myśli literackiej noblistki.

W lipcu 2020 roku ukazał się przekład Opowiadań bizarnych Li Yinan cieszący się wielką popularnością zarówno wśród czytelników, jak i krytyków. Wydawnictwo Zhejiang Wenyi Chubanshe - Culture Key potraktowało publikację tej pozycji jako ważne instytucjonalnie wydarzenie. Szczególnie że było to pierwsze wydanie opowiadań Tokarczuk przełożonych bezpośrednio z polskiego na chiński po przyznaniu autorce Nagrody Nobla, a zarazem dzieło Li Yinan - reprezentantki nowej generacji tłumaczy literatury w Chinach. Na promocji przekładu Opowiadań bizarnych pojawili się znani chińscy pisarze, m.in. Li Er, laureat prestiżowej Nagrody Literackiej im. Mao Duna, uznani krytycy i tłumacze, jak Gao Xing i Zhao Gang, oraz tłumaczka Li Yinan. Promocja była transmitowana online, dzięki czemu blisko 58000 internautów mogło śledzić dyskusję między gośćmi dzielącymi się swoimi interpretacjami twórczości pisarki a tłumaczką opo- 
wiadającą o trudnościach i emocjach towarzyszących jej w trakcie pracy. Chińska wersja Opowiadań bizarnych znalazła się w ponad 10 rankingach książek roku, m.in. 10 najpopularniejszych książek 2020 Douban, Najlepsze książki 2020 „Gazety Literatury i Sztuki”, 32 bestsellery $z$ dziedziny literatury księgarni Sanlian itd. Ponadto prestiżowa chińska „Gazeta Jasności” opublikowała wstęp Czuła troska w grotesce i wielka wyobraźnia we fragmentarycznych opowiadaniach napisany przez tłumaczkę do tego wydania. Idąc śladem pierwszego udanego wydania, młode tłumaczki, studentki Li Yinan, magistrantki polonistyki PUJo, Zhao Zhen i Cui Xiaojing przetłumaczyły Szafę, która ukazała się miesiąc później. Po kolejnych kilku miesiącach, w styczniu 2021 roku, He Juan i Sun Weifeng, młodzi wykładowcy Katedry Języka Polskiego PUjo, przełożyli i wydali powieść Prowadź swój pług przez kości umartych. Obecnie w kolejce do przekładu czeka esej Lalka i perła. Z wyjątkiem ostatniej książki, Czuły narrator, prawa do przekładu pozostałych książek Tokarczuk zostały wykupione przez wspomniane wydawnictwo Culture Key. Przewiduje się, że ich tłumaczenia ukażą się w najbliższych latach.

Analizując dane dotyczące przekładów utworów pozostałych noblistów z dziedziny prozy, czyli Sienkiewicza i Reymonta, można zauważyć, że układają się w trzy kategorie: a) nowe tłumaczenia (Komediantka, Listy $z$ Ameryki), b) ponowne lub przerobione tłumaczenia już zaistniałych przekładów (Chłopi, Hania, Quo vadis, Ziemia Obiecana, Latarnik, In Monte Carlo, Krzyżacy) oraz c) ponowne wydania wcześniejszych przekładów. Choć książki te nie budzą dziś takich emocji wśród czytelników i komentatorów rynku literackiego, jak kolejne pozycje z dorobku Tokarczuk, to zainteresowanie klasykami polskiej prozy utrzymuje się na wysokim poziomie. Więcej na temat przyczyn ich popularności przeczytać można we wspomnianej publikacji Li Yinan Literatura polska $w$ Chinach.

Kolejnym nietuzinkowym polskim prozaikiem znanym wśród Chińczyków jest Andrzej Sapkowski. Już w 1986 roku chiński miesięcznik „Świat S-F/Przekłady”, który publikuje tłumaczenia

3 Nakład czasopisma to 130 tys. egzemplarzy. Do głównej edycji dołączany jest dodatek „Translations”. 
zachodnich opowiadań science fiction i fantasy, zamieścił na swoich łamach debiutanckie opowiadanie Sapkowskiego. Od 2015 do 2020 Wu Lan, Xiao Long, Zhao Lin i Ye Zhijun przetłumaczyły prawie wszystkie części Wiedźmina, m.in. Miecz przeznaczenia, Chrzest ognia, Krew elfów, Czas pogardy, Wieże jaskótki, Panią Jeziora, Ostatnie $\dot{z}$ yczenie. Nie tylko sama literatura fantasy Sapkowskiego zyskała miłośników w Chinach, niezwykle popularne stały się również gry komputerowe stworzone na podstawie Wiedźmina. Latem 2016 roku Studio CD Projekt RED (twórcy gry Wiedźmin 3: Dziki Gon) oraz GAEA (jeden z najszybciej rozwijających się chińskich dostawców interaktywnej rozrywki) ogłosili nawiązanie współpracy, której celem było wydanie gry Gwint: wiedźmińska gra karciana na terenie Chin. Na okładce wyżej wspomnianego czasopisma znalazł się wizerunek Geralta z gry komputerowej. Całe, ponad stupięćdziesięciostronicowe wydanie poświęcone zostało Wiedźminowi. Opowiadania zajęły 110 stron pisma, a aż 10 poświęcono grze komputerowej. W magazynie zamieszczono także obszerną notkę biograficzną Sapkowskiego oraz ciekawy artykuł pt. Zauroczony tragizmem bohatera, w którym tłumacz zawarł osobiste przemyślenia na temat prozy Sapkowskiego [Straganiarz 2016]. Takie zjawisko narodziło się, gdyż na obecnym etapie rozwoju technologii gracz zamienia się w bohatera swoich światów. Z dużym prawdopodobieństwem można przyjąć, że adaptacja literatury do postaci gry komputerowej jest również jedną ze skutecznych metod promocji literatury polskiej w Chinach.

Warto dodać, że chińscy czytelnicy zainteresowali się także twórczością Brunona Schulza i Sławomira Mrożka za sprawą takich utworów, jak Sanatorium Pod Klepsydra, Sklepy cynamonowe, Ulica Krokodyli czy Słoń oraz Krótkie, ale całe historie w tłumaczeniach Lin Weiyun i Mao Yinhui. Pierwsza tłumaczka zajmowała się głównie pisarzem z Drohobycza, zaś druga autorem Tanga. Mao napisała ponadto artykuł naukowy opublikowany w "Języku Polskim”, w którym opisała trudności w tłumaczeniu Mrożka. Wydaje się jednak, że te same uwagi można by z powodzeniem odnieść także do wyzwań stających przed tłumaczką Schulza:

[... podejmowanie trudu tłumaczenia i przybliżania czytelnikowi chińskiemu twórczości Stanisława Mrożka jest bardzo 
odpowiedzialnym i trudnym zadaniem ze względu na różnice międzyjęzykowe i międzykulturowe. Tłumacz powinien znać historię, realia i konotacje związane z wyrażeniami językowymi, stereotypami, schematami; pomocna jest nie tylko wiedza o współczesnej polszczyźnie, ale też o gwarach, historii języka, odmianach stylistycznych. W wypadku tak odległych strukturalnie języków jak polski i chiński dochodzą jeszcze bariery gramatyczne. [Mao, Sękowska 2019: 108-117]

Mimo tych trudności Krótkie, ale całe historie zajęły czołowe miejsce w rankingu Najlepsze ksiązki roku 2018 opublikowanym przez „Gazetę Nowy Pekin”.

\section{Podmioty translatorskie - dwie generacje tłumaczy}

Odpowiedziawszy na pytanie „Co zostało przetłumaczone?”, powinniśmy się zastanowić, kto podjął wyzwanie tłumaczenia polskich utworów literackich. W Chinach uważa się powszechnie, że tłumacz jest głównym podmiotem działalności translatorskiej, a także ważnym uczestnikiem procesu kształtowania kultury narodowej. Mimo że dawniej podmiotowość tłumacza była ignorowana $\mathrm{w}$ wielokulturowości Chin, to w ostatnich latach jego rola w rozpowszechnieniu literatury zagranicznej zaczęła rosnąć. Właściwym przykładem jest dwukrotne przyznanie nagrody translatorskiej najwyższego szczebla w Chinach: Nagrody Kultury Translatorskiej za całokształt dwojgu najwybitniejszym tłumaczom literatury polskiej, a więc Yi Lijun i Lin Hongliangowi, w roku 2018 i 2019. Komisja w laudacji zaznaczyła, że Yi wniosła ogromny wkład w tłumaczenie, zagraniczną promocję i wymianę kulturową, osiągnęła na tym polu wybitne zasługi, doceniane przez krytyków literackich. Celem tej nagrody jest więc zwrócenie większej uwagi całego społeczeństwa na zawód tłumacza i szacunek dla jego dorobku. Jednocześnie powinna zachęcać przedstawicieli młodego pokolenia do podejmowania dalszej nauki i pielęgnowania szlachetnej etyki zawodowej, poświęcenia wobec swoich obowiązków zawodowych, odpowiedzialności społecznej i misji odrodzenia narodu oraz promowania postępu społecznego. Portal Chińskie Wiadomości 
(Zhongguo Xinwenwang) z tej okazji opublikował wywiad z Lin Hongliangiem. Badacz relacjonowal, że aktualnie (od powrotu do kraju ze studiów w Polsce) pracuje w Chińskiej Akademii Nauk Społecznych, a specjalizuje się w tłumaczeniu i badaniu literatury polskiej. W wywiadzie sformułował przesłanie do młodych tłumaczy:

Powinniśmy potrafić badać, pisać eseje i rozprawy naukowe, a także tłumaczyć dzieła literackie. Bez tłumaczenia dzieł literackich większość czytelników nie będzie w stanie zrozumieć świata literatury danego kraju, a książka, nieważne, jak dobra, wciąż będzie niegotowa. Przez 60 lat Lin Hongliang zbudował most, który skrócił dystans między chińskimi czytelnikami a polskimi pisarzami. [Liu 2019]

Zasługi starszych tłumaczy powoli, choć efektywnie inspirują młode pokolenie tłumaczy do podejmowania trudnej misji przekładu, nie tylko językowego, lecz także kulturowego. W odpowiedzi na coraz większe potrzeby rynku wydawniczego i kontaktów kulturalnych między Chinami a Polską nestorzy zachęcali i zachęcają młodszych polonistów do tłumaczenia i promocji literatury polskiej w Chinach. Yi Lijun i Lin Hongliang w różnych okolicznościach powtarzali, że poświęcili całe życie literaturze polskiej, która była, jest i będzie ich pasją do końca. Schodząc ze sceny, chcieliby przekazać swoje doświadczenia i umiejętności młodszemu pokoleniu. Takie podeście znakomicie wyraża konfucjański idiom „przekazywania pochodni z pokolenia na pokolenie”. Z inicjatywy Yi Lijun pojawiły się przekłady współautorstwa seniora i młodych tłumaczy, np. Słoń Mrożka (przekład: Mao Dun i Yi Lijun). Yi Lijun poleciła chińskim wydawnictwom Li Yinan do uczestnictwa w promocji, interpretacji i tłumaczeniu twórczości Tokarczuk w Chinach. Liczne artykuły na temat noblistki i sukces Opowiadań bizarnych wskazują, że taki sposób dziedziczenia można uznać za udany. Z kolei Lin Hongliang umożliwił wielu młodym polonistom pokazanie swoich talentów w tłumaczeniu literackim. Przyjął propozycję przetłumaczenia wszystkich dzieł Szymborskiej w stosunkowo krótkim czasie, złożoną przez Centrum Wydawnicze 
Wschodu w Szanghaju, ale polecił aż sześciu młodych tłumaczy do pracy nad poszczególnymi tomami.

Wyliczając wszystkich młodych tłumaczy, można zauważyć, że w ostatnich sześciu latach 14 młodych polonistów brało udział w thumaczeniu literatury polskiej w Chinach. Statystyka ta z jednej strony świadczy o wysokiej aktywności rynku wydawniczego i dużym zapotrzebowaniu na literaturę polską wśród chińskich czytelników, a z drugiej strony odzwierciedla dynamiczny rozwój kształcenia polonistycznego w Chinach. W roku 2009 w Harbinie powstała dopiero druga chińska polonistyka, po 55 latach istnienia jedynej polonistyki na PUjo, a do roku 2021 w Państwie Środka założono ponad 20 ośrodków nauczania języka polskiego i kultury polskiej. Szacuje się, że co roku w Chinach blisko 100 studentów polonistyki ukończy studia i zasili rynek pracy. Wielu z nich stanie się nowymi, pełnymi witalności uczestnikami grupy promującej kulturę polską w Chinach. Pisząc o młodym pokoleniu tłumaczy, nie możemy zapominać o ich wzorach, czyli kadrze naukowo-dydaktycznej. Jej przedstawiciele na wielu chińskich polonistykach sami tłumaczą polskie teksty, wskazując na najlepsze strategie i umiejętności translatorskie ${ }^{4}$. Wspólne zamiłowanie do literatury polskiej skłoniło ich do szerzenia misji promocyjnej dorobku Tokarczuk, Miłosza i nie tylko.

Dość interesującą postacią z grona polskojęzycznych tłumaczy jest, oprócz osób wymienianych już wielokrotnie, Lin Weiyun, której doświadczenie z językiem polskim i literaturą polską bardzo zaciekawiło czytelników. Lin urodziła się na Tajwanie, studiowała za granicą w Anglii. Po przeczytaniu angielskiej wersji opowiadań Schulza była tak głęboko poruszona, że zdecydowała się pojechać do Polski, aby nauczyć się języka polskiego od podstaw. Pragnęła pewnego dnia przełożyć prace tego autora na język chiński i w ten

Warto wymienić kilkoro młodych tłumaczy i zarazem pracowników dydaktycznych: Li Yinan, He Juan i Sun Weifeng - PUjo; Mao Yinhui, Liang Xiaocong, Lin Xin - Kantoński Uniwersytet Studiów Zagranicznych; Gong Ningbo - Uniwersytet Studiów Międzynarodowych w Tianjinie; a ponadto magistrantki i doktorantki studiów polonistycznych: Zhao Weiting, Cui Xiaojing, Zhao Zhen i Zhang Huiling; a także absolwentów polonistyki PUjo, np. Wu Yu, Zhao Lin, Gong Lingxi, obecnie związanych z innymi instytucjami. 
sposób zaprezentować jego dzieła większej liczbie czytelników. Kilka lat później nie tylko przetłumaczyła dwa krótkie zbiory opowiadań Schulza, czyli Ulicę Krokodyli i Sanatorium pod Klepsydra, lecz także została zdobywczynią honorowego medalu za wkład w kulturę narodu polskiego i wieloletnie zaangażowanie $\mathrm{w}$ wymianę kulturową Polski. Jej pierwsza próba tłumaczenia literatury polskiej jednak nie dotyczyła Schulza, ale Sapkowskiego - Ostatniego życzenia i Miecza przeznaczenia z serii Wiedźmin. Następnie Lin Weiyun przetłumaczyła utwory dwóch polskich mistrzów: Czarna piosenkę Szymborskiej i Ulicę Krokodyli Schulza - autora, który zainicjował relację Lin Weiyun z Polską. Tłumaczka przyznała:

Twórczość Brunona Schulza jest bardzo trudna. Zawiera nie tylko dużo archaizowanych form językowych, lecz także neologizmy stworzone przez autora. W języku polskim występuje tzw. zmiana szyku zdania. Podmiot i odbiorca mogą zmienić swoje pozycje. Czasami jeden akapit jest napisany za pomocą jednego ciągłego zdania złożonego z czterech lub pięciu wierszy, więc trudno jest określić, kto jest podmiotem. Schulz wykorzystuje tę właściwość języka polskiego do granic możliwości, można uznać jego pracę za „ucztę polskości”. Natomiast tłumacz musi odnaleźć początek nici w tym labiryncie zdań i słów. Jednak najtrudniejszym zadaniem w trakcie tłumaczenia Schulza jest uchwycenie atmosfery obecnej w jego pracach. Jego utwory charakteryzują się przedstawianiem scen z codziennego życia w poetycki i oniryczny sposób. Jeżeli ktoś nie widział tego na własne oczy, to trudno będzie mu zrozumieć, dlaczego Schulz opisał to w ten sposób. W związku z tym przy tłumaczeniu jego utworów nie tylko trzeba ciężko pracować w domu, lecz także poważnie podchodzić do życia, aby móc zrozumieć i uchwycić ducha jego tekstów. [Chinamediatime 2019]

Wypowiedź ta jest idealną konkluzją starań chińskich tłumaczy, dążących do właściwego zrozumienia tekstu, szlifowania języka ojczystego, „topnienia” w myślach pisarzy i oddania ducha ich twórczości. 


\section{Nowe kryteria w badaniu i odbiorze literatury polskiej w Chinach}

W latach 2015-2020 pojawiło się kilka nowych ważnych osiągnięć w badaniach nad literaturą polską w Chinach. Wybitny tłumacz, specjalista literatury polskiej Zhang Zhenhui wydał Historię literatury polskiej XX wieku (2017) i dwutomowy Zarys historii literatury polskiej (2019). To monumentalne wydanie stanowiło panoramiczny i nowoczesny przewodnik literacki dla chińskich czytelników. Ukazał się również naukowy tom pokonferencyjny pt. Chińsko-polska wymiana literacka nowego wieku: przeglad i perspektywa (2016), w którym zamieszczono ok. 20 referatów dotyczących recepcji literatury polskiej w Chinach napisanych przez chińskich i polskich specjalistów. W roku 2017 uruchomiono program „Przegląd literatury zagranicznej”. W ramach tej akcji zbierano najświeższe informacje o wydarzeniach związanych z twórczością i badaniami literackimi prowadzonymi w poszczególnych krajach. Li Yinan aktywnie uczestniczyła w programie. Co roku tworzyła raport zawierający przegląd literatury polskiej. Na podstawie nominowanych, finałowych i wyróżnionych prac w ramach dwóch najważniejszych literackich nagród w Polsce - Nagrody Literackiej Nike i Nagrody Literackiej Gdynia - przedstawiła dziesiątki polskich pisarzy i ich twórczość według czterech kategorii, tj. poezji, powieści, eseju i reportażu. Dzieła te zwrócily uwagę świata literackiego oraz zyskały uznanie jego przedstawicieli. Poza tym raporty tworzone w ramach „Przeglądu ...” prezentują różne cieszące się dużym zainteresowaniem działania edukacyjne oraz promocyjne w zakresie literatury, które są prowadzone przez rząd polski i instytucje kulturalne z okazji „Roku Sienkiewicza”, „Roku Konrada”, „Roku Herberta” i „Miasta Literatury” w Krakowie. Szczególną wagę przywiązywano do przedstawienia Tokarczuk z okazji przyznania jej Nagrody Bookera i Nagrody Nobla. To systematyczne działanie promujące literaturę polską będzie jeszcze kontynuowane w przyszłości jako „żywy” przewodnik literatury polskiej w Chinach.

Patrząc na wykres (3) opublikowanych rozpraw naukowych skupiających się na twórczości poszczególnych polskich pisarzy, znajdujemy różnicę między działalnością translatorską a zaintere- 


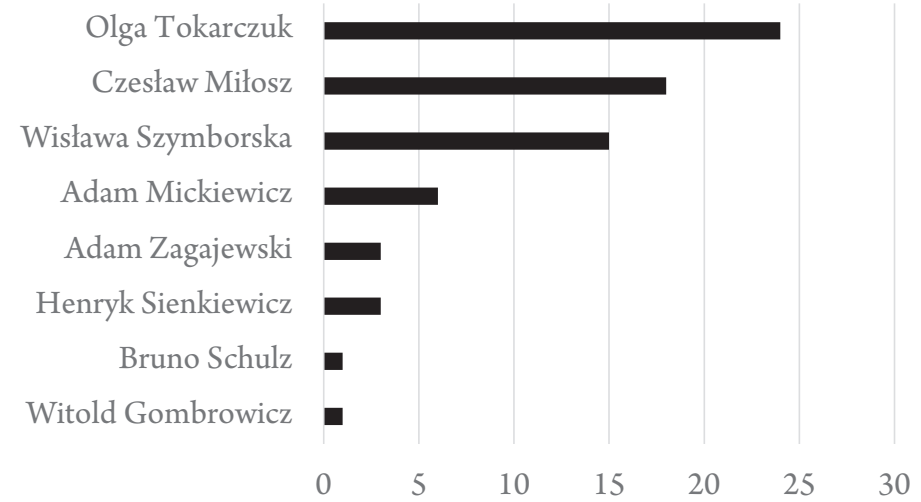

Wyk. 3. Liczba opublikowanych w Chinach rozpraw naukowych poświęconych poszczególnym pisarzom polskim

sowaniem chińskich badaczy. Dzięki nagrodom Bookera i Nobla Tokarczuk bezapelacyjnie zajmuje pierwsze miejsce na liście ośmiorga pisarzy, którym poświęcono najwięcej refleksji naukowej i studiów. Natomiast Sapkowski, którego powieści były najczęściej wydawane, nie został w ogóle zauważony przez chińskich krytyków (nie analizowano go pod kątem naukowym). Inaczej mówiąc, Wiedźmin cieszył się popularnością raczej wśród graczy komputerowych i fanów gatunku fantasy.

Warto zwrócić uwagę na znaczącą zmianę w sposobie odczytywania literatury. Transformacji tej towarzyszą nowe narzędzia teorii literatury i postmodernistyczne podejście do dzieła literackiego. Tradycyjna interpretacja danego utworu, czyli streszczenie historii, analiza sposobu narracji, wyciąganie wniosków z relacji odautorskiej, została zastąpiona nowoczesnymi metodami krytyki literackiej, które często opierają się na zachodnich teoriach literackich. Znakomitym przykładem tego typu badania jest rozprawa naukowa pt. Nowoczesne przedstawienie kobiecości w twórczości Henryka Sienkiewicza: Kobiety, bohaterki i święte autorstwa Li Yinan. W swojej pracy, opublikowanej w czasopiśmie „Literatura Zagraniczna” („Waiguo Wenxue”) - najbardziej prestiżowym chińskim periodyku z dziedziny krytyki literackiej - autorka, posiłkując się teorią gender, analizuje wielorako tożsamość kobiet w różnych 
odsłonach kobiecości: kobiety, bohaterki i świętej, w dziełach Sienkiewicza pod kątem trzech aspektów, tj. ciała, zachowania i religii. Badaczka doszukuje się, mimo dominującej narracji historycznej, wyrazistych pierwiastków bojującej kobiecości w portretach bohaterek Sienkiewicza. Wskazuje na próbę pokonania przez nie społeczno-obyczajowych ograniczeń obowiązujących w czasach, w których przyszło im żyć. Ten rodzaj nowoczesnego myślenia jest zgodny z tzw. konstruktem kobiety w teorii płci społecznej. Opisywanie dotyczy kobiecości - nie tylko kobiecego ciała, lecz także podobieństwa jego fizjologii z kulturą społeczną czy też duchowego charakteru kobiet będących poza granicami sekularnego świata oraz religijnej pogoni za duszą [Li 2019: 50-57].

Li Yinan [2017: 130] w książce Literatura polska $w$ Chinach przekonuje, że w oczach Chińczyków literatura ojczyzny Fryderyka Chopina ma wyraźne cechy charakterystyczne, są to: wyjątkowo silna świadomość narodowa i górujący nad wszystkim patriotyzm, ukazany w powieściach historycznych Sienkiewicza, epopei i dramatach Mickiewicza oraz powieściach Reymonta, Elizy Orzeszkowej czy Jarosława Iwaszkiewicza, a także prezentowanie historii napadów, okupacji, upokorzenia, męki, a w końcu nieposkromionej walki przeciw najeźdźcom. Autorka dodaje ponadto, że ten obraz literatury polskiej jest „zniekształcony i uszkodzony”, a komplikacje w życiu rodzinnym i społecznym, przygody, samopoczucie człowieka, często są tematem, który wymaga zrozumienia tła społeczno-historycznego. Opublikowane w latach 2015-2020 rozprawy naukowe (ponad 70) badające polskie utwory literackie w Chinach pokazują wiele innych, nowych, do tej chwili nieznanych interpretacji literatury polskiej oglądanej oczami Chińczyków. Swoją analizę oprę na kilku kryteriach i wzmocnię przykładami oraz własną refleksją. Pierwszym kryterium jest „polskość”, czyli zakorzenienie w tradycji i historii, drugim - otwartość literatury na nowoczesność i eksperyment oraz swoistą grę między „polskością a niepolskością”, trzecim - przesłanie i wymiar uniwersalnej moralności.

Zacznę od kryterium pierwszego: literatura polska jest głęboko zakorzeniona w historii i tradycji państwa polskiego. Nie ulega wątpliwości, że literatura jako droga do wyobrażenia i poznawania 
historii posiada szczególną moc. Chiński noblista Mo Yan w swojej narracji historycznej przedstawia schyłkową fazę chińskiej cywilizacji rolniczej, wykazując się jako pisarz ogromnym poczuciem odpowiedzialności narodowej. Potrafi opisywać charakter żyjących niegdyś ludzi, prezentując przy tym bogate życie na wsi. Dzięki ożywionej interakcji historii i rzeczywistości jego powieści znalazły ważne miejsce w literaturze światowej. Podobną, czy nawet wyższą, pozycję osiągnął polski noblista Sienkiewicz - dzięki swoim powieściom historycznym. We wspomnianym artykule o tożsamości kobiet w dziełach Sienkiewicza badaczka zwróciła czytelnikom uwagę na znaczenie Polek w rozwoju historii państwa polskiego. Analizując postać Baśki w Panu Wołodyjowskim, autorka zauważyła, że w powieściach historycznych Sienkiewicza są opisywane narodowe dążenia do wolności, niepodległości i wyzwolenia ojczyzny u schyłku XIX wieku, kiedy państwo polskie było pod zaborami. Sienkiewicz, przedstawiając cierpienie i tragedię Polek w czasach wojny, ukazuje również spryt przetrwania i podążanie za moralnością w obliczu wszelkiego rodzaju cierpień. Podkreśla osobowość tych kobiet, ich ogromną inteligencję oraz szlachetne zasługi jako „bohaterek” narodowych. Stara się również odnaleźć w literaturze i historii ukryte i zapomniane historyczne osiągnięcia Polek.

Historia xx wieku została opisana w powieści Prawiek $i$ inne czasy Tokarczuk. Qu Huiyu, komentując tę swoistą sagę, zaznaczyła, że

Prawiek $i$ inne czasy to współczesny mit oparty na symbolicznych ramach przeszłości, teraźniejszości i przyszłości. Opowiada o radości i cierpieniach kilku generacji od I wojny światowej do czasów po II wojnie światowej. Ich życie odzwierciedla burzliwą historię Polski w xx wieku. Autorka z nadzwyczajnym spokojem opisuje traumę, jakiej doznała Polska w czasach wojny. [Li 2019]

Według chińskich badaczy polscy pisarze często czerpią inspirację do budowy świata przedstawionego i narracji z tradycyjnych obrzędów ludowych. Jin Anping [2016: 96-97] w recenzji spektaklu Dziady napisał, że Mickiewicz stworzył epos adaptowany potem 
na scenie, który pokazał starożytną formę ofiar ludowych. To jest podwójny cud z dziedziny poezji i dramatu. Po pierwsze dzięki temu repertuarowi czy przekładowi chińscy widzowie i czytelnicy mieli okazję poznać rytuały staropolsko-kresowe, które były symbolem polskości. Obrzędowe dziady były jednocześnie formą ofiary ludowej i swego rodzaju obrazem uporu i wiary Polaków. Celem rytuału dziadów było złożenie ofiary dla własnych krewnych, a nie ofiary ku czci i chwale Boga. Miejsce, w którym odbywał się taki rytuał, było tajne, choć zazwyczaj dochodziło do niego w starej kaplicy czy przycmentarnym kościółku. Ten rodzaj tajemniczej ofiary w ciemnościach nie wywoływał żadnego strachu, ale był swego rodzaju tajemniczą walką sił ciemności i świata nadprzyrodzonego. Pozostawał mocno związany z wiarą prostego ludu, który był przekonany, że świat ducha może udzielić mu właściwych wskazówek, jak żyć.

Po drugie literatura polska, mimo właściwego jej zainteresowania tradycją i historią, w związku z czym niektóre jej dzieła czytelnikowi zagranicznemu mogą wydać się hermetyczne, jest także otwarta na nowoczesność. Wystarczy spojrzeć na szczególny rozwój literatury polskiej science fiction, by wspomnieć twórczość Lema, czy fantasy, przywołując popularnego na całym świecie Sapkowskiego. Otoczona szczególnym kultem proza Tokarczuk, pokonująca granice zwyczajności, stanowi doskonałe świadectwo tego, że literatura polska nie tylko jest przepojona patriotyzmem i cierpieniem narodowym, ale także otwiera bramy uniwersalnego porządku wszechświata.

Gdy chińscy czytelnicy rozmawiają o Tokarczuk, często porównują jej twórczość z chińskim pisarzem Mo Yanem i autorem Stu lat samotności Gabrielem Márquezem, a Prawiek i inne czasy nazywają polską wersją Stu lat samotności. Podkreślano, że w Prawieku... pojawia się charakterystyczny realizm magiczny. Poprzez magię oraz oszczędną i fragmentaryczną narrację czasową Tokarczuk osiąga połączenie fikcji i rzeczywistości w tajemniczym i niejasnym świecie. Powieść nie tylko wzbudza w ludziach pragnienie „poszukiwania własnych korzeni” i dążenie do „arkadii”, w której ludzie żyją w zgodzie z naturą, ale również ukazuje historyczne przemiany Polski w minionym stuleciu. Tokarczuk zestraja mity, 
sny i biografie świętych w jedną całość, a także łączy ze sobą różne gatunki literackie, takie jak powieść, esej, pamiętnik i inne. W ten sposób tworzy archaiczny świat, który jest zarówno prawdziwy, jak i barwny. Ta oryginalna kreacja krainy snów i niesamowita fabuła są czymś dotąd niespotykanym w europejskiej literaturze [Gao 2020: 5-14].

Szwedzka Akademia przyznała Tokarczuk Literacką Nagrodę Nobla za „wyobraźnię narracyjną, która z encyklopedyczną pasją reprezentuje przekraczanie granic jako formy życia" [Tokarczuk 2019]. Warto podkreślić, że nowinką w odbiorze było dotykanie przez pisarkę sfery nowoczesnych technologii i nauk ścisłych. Wiedza ta nie była katalogiem języka specjalistycznego i terminów naukowych, ale została przefiltrowana przez jej wyobraźnię w poetycką część utworów.

Wielu krytyków zachwyciło się Transfugium z Opowiadań bizarnych, które stworzyło świat postmodernistyczny, gdzie mięso było produkowane $\mathrm{z}$ inkubatorów, ludzie $\mathrm{w}$ dużym stopniu pokonali naturę, ale jednocześnie zostali pokonani przez technologię. Redaktorka przekładu zauważyła:

Olga Tokarczuk w wielu swoich opowiadaniach stworzyła świat z przyszłości. Autorka rzadko mówi wprost, w jakim konkretnie czasie dzieje się akcja opowiadania, zamiast tego daje czytelnikowi wskazówki poprzez obecne w opowiadaniu wysoko rozwiniętą technologię, zimną sztuczną inteligencję oraz wysoce uporządkowane i wystylizowane życie ludzkie. [Li 2020]

Chińscy czytelnicy zadawali pytanie po lekturze: czy uporządkowany i idealny tryb życia w swojej istocie zmniejsza przestrzeń życiową ludzi? Jeżeli to wszystko naprawdę zostanie zrealizowane w przyszłości, życie ludzkie będzie coraz bardziej schematyczne, przewidywalne, powierzchowne i monotonne, a duchowość ludzi będzie stopniowo zanikać pod wpływem zalewu informacji oraz zaawansowanej nauki i technologii.

Nowoczesność literatury polskiej polega jeszcze na konfrontacji „polskości” z „niepolskością”. Pierwszy nurt reprezentują 
Mickiewicz, Sienkiewicz i Miłosz, bardzo mocno zespoleni z tematyką narodową i patriotyczną. Każdy z nich na swój własny sposób interweniuje w zastaną rzeczywistość społeczno-polityczną, a także z literatury czyni pewnego rodzaju broń. Ponadto pisarze ci twierdzą, że literatura powinna służyć narodowi, a każdy z nich chciał stać się trybunem ludu, aby wyrażać jego potrzeby i dawać świadectwo prawdzie. Z kolei nurt „niepolskości” odnajdziemy u takich autorów, jak Gombrowicz, Schulz czy Szymborska. Gao Xing [2020] oceniał, że

twórczość W. Gombrowicza jest alternatywna w sensie świadomości, pod tym względem jest on również najbardziej znanym polskim pisarzem. Jednocześnie oddalając się od tradycji i formy, podkreślał, że literatura powinna być niezależna. Jego dzieła są pełne absurdu, osobliwości i gier. Jego wyjątkowy wkład dotyczy wprowadzenia nowoczesności do literatury polskiej.

Schulz jest kolejnym „samotnikiem” w literaturze polskiej, któremu blisko było do świata przedstawionego Franza Kafki. Dodatkowo zwrócił się w stronę swojego serca, świata fikcyjnego, oniryzmu i kreacjonizmu jako chwytów konstruujących świat jego prozy.

Na początku swojej kariery pisarskiej Szymborska „zabłądziła” i napisała kilka poematów w odpowiedzi na zaistniałą sytuację polityczną, podbudowaną silnie socrealizmem. Jednakże zmieniła się wraz z biegiem czasu i zaczęła mierzyć się z poważnymi tematami w sposób taktowny, delikatny, ironiczny oraz humorystyczny, kształtując swój nietuzinkowy styl pisarski. Nie napisała wiele, ale jej każdy wiersz był majstersztykiem.

Każdy z tych pisarzy posiadał swego rodzaju „niepolskość”, która akurat stała się ich znakiem rozpoznawczym i pozwoliła im zdobyć sławę na całym świecie.

Jeśli chodzi o kryterium trzecie, dotyczące przesłania, to zaznaczę na wstępie, że literatura polska jest ściśle związana z troską o losy ludzi i świata. Rozumiem przez to swego rodzaju apelatywność literatury polskiej, jej przesłanie moralne oraz postawy i wartości, które kreuje. Zacznę od analizy przemówie- 
nia noblowskiego Tokarczuk. Pisarka z właściwą sobie troską zajmuje stanowisko w sprawach kryzysów wywołanych postępem i nowoczesnością.

Kryzys klimatyczny i polityczny, w którym dzisiaj próbujemy się odnaleźć i któremu pragniemy się przeciwstawić, ratując świat, nie wziął się znikąd. Często zapominamy, że nie jest to jakieś fatum i zrządzenie losu, ale rezultat bardzo konkretnych posunięć i decyzji ekonomicznych, społecznych i światopoglądowych (w tym religijnych). Chciwość, brak szacunku do natury, egoizm, brak wyobraźni, niekończące się współzawodnictwo, brak odpowiedzialności sprowadziły świat do statusu przedmiotu, który można ciąć na kawałki, używać i niszczyć. [Tokarczuk 2019]

Ta pełna wyważonej emocjonalności diagnoza staje się przesłaniem literatury w ogóle, zaś słowa wypowiadane przez polską pisarkę wpisują się w nową narodową postawę polskich pisarzy, którzy nie mogą obojętnie spoglądać na rozwój świata i jego niekontrolowalną automatyzację.

Wielu chińskich krytyków podziela taką troskę o los świata. Zhou Si [2020] w recenzji Opowiadań bizarnych analizował scenę w Górze wszystkich świętych: w Indiach, na cmentarzu świętych krów, siostra widziała okropny krajobraz - skręcone, na wpół nadtrawione torebki plastikowe, $\mathrm{z}$ widocznymi wciąż napisami sieciowych marek, sznurki, gumki, nakrętki, kubeczki. Żaden organiczny sok trawienny nie dawał rady zaawansowanej ludzkiej chemii. Krowy zjadały śmieci i niestrawione nosily je w swoich żołądkach. Ciało znika zjedzone przez owady i drapieżniki. Zostaje to, co wieczne. Śmieci.

Ten obraz opisuje nasze życie we współczesnym świecie, które jest zatopione przez ludzkie odpady. Ten problem środowiska ostatecznie wystawił na próbę granice ludzkiej wiary, stając się trudnym do wyleczenia bólem egzystencjalnym. [Zhou 2020]

Badacz kontynuuje swoje rozważania, podkreślając, że 
historia świętych, badania prowadzone na dzieciach oraz fragmenty Indii stworzyły przeszłość, przyszłość i teraźniejszość. Ukryty motyw eksperymentów klonowania jest zakorzeniony w bólu, którego współcześni ludzie nie są w stanie się wyzbyć. W związku z tym pragną uzyskać wyzwolenie z rąk nowo narodzonych świętych. Dlatego też na końcu opowiadania główna bohaterka, która jest śmiertelnie chora, prosiła dziecko, aby położyło swoją dłoń na jej sercu i powiedziało, że jest to miejsce, którego potrzebuje najbardziej. Poprzez to dowiadujemy się, co właściwie jest przyczyną jej choroby i tym właśnie jest choroba mentalności współczesnego społeczeństwa. [Zhou 2020]

Postawa ekologiczna po raz pierwszy w literaturze polskiej została zauważona przez chińskich krytyków u Szymborskiej. Wu Chaoping w swojej rozprawie pt. Analiza myśli ekologicznej Wistawy Szymborskiej na przykładzie „Wotania do Yeti” interpretował manifestacje literackie poetki w tym zbiorze. Ekologiczna myśl Szymborskiej zakłada równość wszystkiego, co nas otacza, i sprzeciwia się krzywdzeniu tego. Ta myśl nawołująca do uniwersalnej miłości zmusza nas do głębszej kontemplacji. W tomiku poezji Wołanie do Yeti Szymborska mówi o tym, że wszystko jest równe, a przetrwanie dotyczy nie tylko ludzi. Inne istoty również mają motywację i prawo do przeżycia. Żadna istota nie jest zależna od ludzkiej woli, każda jest samodzielna i samowystarczalna. W wierszach Szymborskiej każda istota posiada swój własny, wyodrębniony mikroświat. Wu Chaoping w swoim artykule zaznacza, że Szymborska nienawidzi bezlitosnego plądrowania oraz poddaje krytyce okrutne ludzkie działania zmierzające do podporządkowania zwierząt człowiekowi. Poza tym ostro piętnuje samolubność ludzkiej natury i pogardza imperializmem, który doprowadził do zniewolenia innych narodów. Sprzeciwia się opresyjnej władzy rządzących i nie jest w stanie tolerować polityki czystki etnicznej. Protestuje przeciwko wojnom zapoczątkowanym przez silne mocarstwa i martwi się o kryzys ekonomiczny obecny w społeczeństwie. Mimo wszystko Szymborska daje czytelnikom nadzieję na pokrycie świata blaskiem miłości oraz na to, że wszystkie istoty żywe będą wspólnie o siebie dbały i kochały się nawzajem, a ludzie 
będą współistnieć szczęśliwie z innymi istotami we wszechświecie. Poetka wierzy również, że przyszłość rodzaju ludzkiego znajduje się w naturze, a ona nie jest naznaczona współczesną cywilizacją. Tylko życie w takim środowisku naturalnym pozwoli ludziom na nowo się odrodzić i uzyskać szczęście.

Zaprezentowane przeze mnie kryteria nowej lektury tekstów polskich w Chinach świadczą o wciąż żywej potrzebie sięgania po literaturę, która oferuje tak wiele: od treści narodowych przez ich swoistą krytykę aż do tematów z pogranicza nauki, aksjologii i ekologii.

\section{Zakończenie}

Nie ulega wątpliwości, że literatura polska na chińskim, największym rynku wydawniczym na świecie, ma już właściwe sobie, godne miejsce. Jest ona analizowana pod względem krytycznoliterackim i za pomocą nowych narzędzi teorii literatury, a także przez indywidualne konkretyzacje zwyczajnych chińskich czytelników, którzy komentując literaturę polską w mediach społecznościowych, na portalach, takich jak wspomniany przeze mnie Douban, propagują ją i zachęcają innych do lektury. Polska ma swoje ważne miejsce w świadomości literackiej Chińczyków, co oczywiście potwierdza uzyskanie przez polskich pisarzy pięciu Nagród Nobla.

Spoglądając na liczby przekładów i rozpraw naukowych, można stwierdzić, że recepcja literatury polskiej w Chinach osiągnęła bezprecedensowy poziom w latach 2015-2020. Nie tylko jakość przekładów zyskała uznanie zarówno specjalistów, jak i czytelników, ale także sposób odczytania dzieł literackich został w wysokim stopniu unowocześniony. Krytycy i czytelnicy wykazują szacunek wobec literatury i tradycji opisanej w literaturze polskiej, doceniają nowoczesną i nowatorską twórczość polskich pisarzy. Najbardziej wzrusza Chińczyków „czułość” polskich pisarzy, którzy troszczą o losy ludzi i wszechświata.

Poszukująca rozwiązań na przyszłość dla ludzi i świata noblistka Tokarczuk jest najbardziej reprezentatywną pisarką nowego nurtu w Chinach. Jej słowa z przemówienia noblowskiego są cytowane i poddawane analizie ze względu na ogromny ladunek troski i empatii, 
czyli właśnie tego, czym kieruje się „czuły narrator”. Pisarka konkluduje w swojej przemowie: „Dlatego wierzę, że muszę opowiadać tak, jakby świat był żywą, nieustannie stawającą się na naszych oczach jednością, a my jego - jednocześnie małą i potężną - częścią" [Tokarczuk 2019]. Wierzy w to, że otaczające nas rzeki, lasy, drogi, słońce, księżyc oraz wszelka fauna i flora - wszystko to, co widzimy, i czego nie widzimy, posiada życie. Jednakże głośne maszyny, ocean informacji, zalewający współczesne społeczeństwo, zagłuszają szepty tego wszystkiego. Sprawiają, że ludzie zaczynają patrzeć na świat w sposób fragmentaryczny, zapominając, że od początku był czymś jednolitym. Człowiek kiedyś był częścią natury, jednak wraz z procesem zmiany w jednostkę społeczną zapomniał o tym, co łączy go z naturą, a także o wszystkim tym, co pochodzi od natury.

$\mathrm{Z}$ tego powodu chińscy odbiorcy chętnie sięgają po twórczość Tokarczuk, by poznać jej kobiecy, podmiotowy, postępowy i pełen bogatych skojarzeń światopogląd. Czytelnicy w Chinach zwrócili uwagę na to, że wielu polskich pisarzy wykorzystuje obecnie czułość i empatię jako narzędzia narracyjne i konstruujące świat przedstawiony.

Chińska interpretacja przemowy noblowskiej Tokarczuk może w idealny sposób konkludować takie rozumienie:

Czułość to stosunek autora do świata. Jest to instynktowna sympatia do wszystkich „nie-ja”. Właśnie za pomocą tego rodzaju delikatnego pędzla opisuje tysiące obiektów na świecie, tak że postacie, wydarzenia, przedmioty, otoczenie itp. pod jej piórem są pokryte warstwą duchowego miękkiego światła, które zachwyca najsubtelniejszą część w sercu czytelnika. [Zhao 2020: 263-271]

\section{Bibliografia}

Chinamediatime (2019), Ttumaczka Czarnej Piosenki - Lin Weixun, [dostęp: 21 marca 2019], https://tinyurl.com/3rpxcad2.

Gao Xing (2020), Gushi beihou, huozhe yichude yiyi [Za historia lub znaczeniem przepetnienia - o twórczości Olgi Tokarczuk], „Literatura w Świecie”, z. 2, s. 5-14. 
Jin Anping (2016), Xianrenji zhong de bolan fankang jingshen [Polski duch buntu w „Dziadach”], „Okno Wiatru Południowego”, z. 1, s. 96-97.

Lefevere André (1992), Translation/History/Culture. A Sourcebook, Routledge, London.

Li Can (2020), Nuojiang dezhu Tokarczuk de guaidan gushi huanxing diandao shijie li de lingxing [Olga Tokarczuk: pobudzić ducha zawróconego świata], „Wiadomości Wieczorne Pekinu”, 7 listopada, [pierwodruk], „Sina”, [dostęp: 24 sierpnia 2020], https://tinyurl. com/4pz4d 38 , [wydanie internetowe].

Li Yinan (2017), Literatura polska w Chinach, Wydawnictwo Uniwersytetu Śląskiego, Katowice.

Li Yinan (2019), Nowoczesne przedstawienie kobiecości w twórczości Henryka Sienkiewicza: Kobiety, Bohaterki i Święte, „Literatura Zagraniczna”, z. 4, s. 50-57.

Liu Bin (2019), On stworzyt okno do poznania literatury polskiej dla chińskich czytelników, [dostęp: 10 listopada 2019], https://cutt.ly/4mDHBwo.

Mao Yinhui, Sękowska Elżbieta (2019), Lingwistyczne aspekty przekładów literatury polskiej na język chiński (ze szczególnym uwzględnieniem opowiadań Stawomira Mrożka), „Język Polski”, z. 4, s. 108-117.

Miłosz Czesław (2016), Piesek przydrożny, przeł. Zhao Weiting, Huacheng, Kanton.

Straganiarz (2016), Wiedźmin popularny w Chinach?, [dostęp: 9 marca 2016], https://tinyurl.com/5x93yth3.

Tokarczuk Olga (2019), Czuły narrator, [dostęp: 1 lipca 2021], https://tinyurl.com/xagkxzux.

Wu Lan (2019), Z notatnika tlumacza literatury polskiej i chińskiej, Wydawnictwo Uniwersytetu Gdańskiego, Gdańsk.

Zajączkowski Wojciech (2019), Wstęp, w: Zbigniew Herbert, Wybór wierszy Zbigniewa Herberta, Huacheng, Kanton, s. 1-2.

Zhao Gang (2009), Wybór wierszy Zbigniewa Herberta, w: Wspótczesna poezja świata, red. Tang Xiaodu, Xichuan, Wydawnictwo Zuojia Chubanshe, Pekin.

Zhao Gang (2019), Płomień moralności w poważnych słowach, w: Wybór wierszy Zbigniewa Herberta, Huacheng, Kanton, s. 1-14.

Zhao Gang (2020), Yi rouqing he minrui wei jingmo de shijie fasheng$d u$ Tokarczuk huojiang yanshuo [Czuły i zagorzaty głos dla cichego świata - odczytanie przemowy noblowskiej Olgi Tokarczuk], „Literatura w Świecie”, z. 2, s. 263-271.

Zhao Weiting (2019), Fanyijia Yi Lijun: Chuhuqilei, bahuqicui - fang zhuming bolan wenxue fanyijia Yi Lijun jiaoshou [Rozmowa z wybitna 
i zastużona ttumaczka literatury polskiej, Panią Profesor Yi Lijun], [dostęp: 24 sierpnia 2021], https://tinyurl.com/y7nb72sk.

Zhou Si (2020), Touguo zhedie shikong de suipian jiangshu xianzai

[Opowieść o teraźniejszości przez pryzmat fragmentów składajacych czas i przestrzeń], „Pekińska Gazeta Młodzieżowa”, 17 lipca, [pierwodruk], [dostęp: 24 sierpnia 2020], https://tinyurl.com/ nfjdrd8w, [wydanie internetowe].

Xuan Shaoqiang (2020), „Ximubo'ersika quanji” shoufa [Debiut Zebranych Dzieł Wisławy Szymborskiej], [dostęp: 1 października 2020], https:// cutt.ly/TmDHXqy.

\section{Li Yinan}

\section{Tender Narration: the New Face of Polish Literature in the Eyes of the Chinese}

The article presents the dynamics, characteristics and the shifting paradigms of the reception of Polish literature in China from 2012 to 2020. The author analyses the reasons for the popularity of the most often translated and read Polish authors on the Chinese publishing market, with particular interest in Czesław Miłosz, Olga Tokarczuk and Andrzej Sapkowski. She also presents the translators - both experienced and often recognised and awarded doyens of Polish studies in China, and those from the intermediate and youngest generations to whom the oldest ones passed the knowledge, skills, passion and the sense of common mission of building cross-cultural dialogue through literature.

Keywords: reception of Polish literature; Polish literature in China; translation of Polish literature; Chinese translators.

Li Yinan - assistant professor, ur. 7 października 1981 roku, kierownik Katedry Języka Polskiego na Pekińskim Uniwersytecie Języków Obcych. W latach 2012-2015 III sekretarz w Ambasadzie Chińskiej Republiki Ludowej w Polsce. Uhonorowana Odznaką „Zasłużony dla Kultury Polskiej” nadaną przez Ministra Kultury i Dziedzictwa Narodowego RP. Zajmuje się wymianą kulturalną między Chinami a Polską od wielu lat. Badaczka i tłumaczka literatury polskiej. Znawczyni studiów międzykulturowych. Jest odpowiedzialna za chiński narodowy grant nauk społecznych na temat wymiany literackiej między Chinami a Polską. Uczestniczy w wielu projektach naukowych na szczeblu państwowym lub ministerialnym. Na jej dorobek naukowy składa 
się ponad 30 referatów naukowych o literaturze, kulturze i glottodydaktyce w chińskich i polskich czasopismach i periodykach. Jest autorką monografii pt. Literatura polska $w$ Chinach nominowanej do Nagrody im. Jana Kochanowskiego w roku 2019. Autorka przekładu Poczty literackiej, czyli jak zostać (lub nie zostać) pisarzem Wisławy Szymborskiej, Opowiadań bizarnych Olgi Tokarczuk i podręcznika Język polski dla początkujacych. 
